\title{
PENERAPAN PIJAT OKSITOSIN DALAM UPAYA MEMPERBANYAK PRODUKSI ASI MELALUI PELATIHAN PARA BIDAN
}

\author{
Yeni Aryani*1, Fatiyani Alyensi ${ }^{2}$ \\ ${ }^{1,2}$ Program Studi D III Kebidanan , Jurusan Kebidanan, Poltekkes Kemenkes Riau; \\ Jl Melur No 103 Pekanbaru/ (0761) 36581/ (0761) 20656 \\ *E-mail : yeni@pkr.ac.id
}

\begin{abstract}
Breastfeeding is the optimal way to provide nutrition and care for babies, the coverage of breastfeeding at the age of 0-6 months is still quite low at 52.3\% which is still below the target. Based on this, the community service team was interested in increasing the knowledge of Midwives About Oxytocin Massage in Efforts to Increase Breast Milk Production.

The implementation of community service activities is aimed at prospective lactating mothers (pregnant), lactating mothers and mothers who give birth at Taman Sari clinic. The activity starts in May 2019 until August 2019 at the Taman Sari Clinic in Peknbaru City. The method of implementing mentoring and applying oxytocin massage consists of refresher knowledge and skills of midwives doing oxytocin massage.

The results of community service can be increased knowledge and skills of midwives in doing oxytocin massage. There was an increase in knowledge of midwives by 53\% and skills by $100 \%$ and all women giving birth to breastfeed their babies. Every maternity mother should be taught oxytocin massage techniques and be a routine care for every maternity mother in an effort to increase milk.
\end{abstract}

Keywords-Application, Oxytocin Massage, Breast Milk Production, Midwife

\section{Abstrak}

Menyusui adalah cara yang optimal dalam memberikan nutrisi dan mengasuh bayi, cakupan pemberian ASI pada umur 0-6 bulan masih cukup rendah yaitu sebesar 52,3\% masih dibawah target. Berdasarkan hal tersebut maka tim pengabdian masyarakt tertarik untuk meningkatkan pengetahuan Bidan Tentang Pijat Oksitosin dalam Upaya Memperbanyak Produksi ASI.

Pelaksanaan kegiatan pengabmas ini ditujukan kepada calon ibu menyusui (hamil), ibu menyusui dan ibu yang bersalin di klinik Taman Sari. Kegiatan dimulai bulan Mei 2019 sampai dengan Agustus 2019 bertempat di Klinik Taman Sari Kota Peknbaru. Metode pelaksanaan pendampingan dan penerapan pijat oksitosin terdiri- dari penyegaran pengetahuan dan ketrampilan bidan melakukan pijat oksitosin.

Hasil pengabdian masyarakat ini dapat meningkatnya pengetahuan dan ketrampilan Bidan dalam melakukan pijat oksitosin. Terdapat peningkatan pengetahuann bidan sebanyak 53\% dan keterampilan 100\% dan semua ibu bersalin sudah memberikan ASI pada bayinya. Hendaknya setiap ibu bersalin harus diajarkan teknik pijat oksitosin dan menjadi asuhan rutin bagi setiap ibu bersalin sebagai upaya memperbanyak ASI .

Kata Kunci-Penerapan, Pijat Oksitosin, Produksi ASI, Bidan

\section{PENDAHULUAN}

World Health Organization dan America Academy of Pediatric (AAP) merekomendasikan pemberian nutrisi yang optimal bagi bayi baru lahir yakni dengan strategi global pemberian ASI eksklusif selama 6 bulan $^{1,2}$. Air susu ibu (ASI) adalah cairan kehidupan yang diciptakan Tuhan khusus bagi bayi yang mengandung sel darah putih, zat kekebalan, enzim, hormon dan protein 
yang cocok untuk bayi ${ }^{3}$. ASI merupakan makanan terbaik bayi pada awal usia kehidupannya. ASI terbukti mempunyai keunggulan yang tidak dapat digantikan oleh makanan dan minuman manapun karena ASI mengandung zat gizi yang paling tepat dan lengkap untuk pertumbuhan dan perkembangan bayi ${ }^{4}$.

Berdasarkan laporan Direktorat Jendral (Ditjen) Gizi dan KIA ${ }^{5}$, cakupan pemberian ASI pada umur 0-6 bulan masih cukup rendah yaitu sebesar 52,3\%. Angka tersebut belum mencapai target pemberian ASI eksklusif tahun 2015, masih rendahnya cakupan ASI eksklusif dikarenakan adanya ideologi makanan yang non eksklusif, pengetahuan ibu yang kurang sehingga tidak muncul motivasi yang kuat dari ibu untuk memberikan ASI eksklusif pada bayinya ${ }^{6}$. Salah satu faktor penghambat dalam pemberian ASI adalah produksi ASI itu sendiri. Produksi ASI yang kurang dan lambat keluar dapat menyebabkan ibu tidak memberikan ASI pada bayinya dengan cukup. Jika ada rasa cemas, stress dan ragu yang terjadi, maka pengeluaran ASI bisa terhambat ${ }^{7}$. Hal ini di dukung oleh penelitian ${ }^{8}$ bahwa alasan paling umum yang menyebabkan kegagalan pemberian ASI eksklusif adalah produksi ASI yang kurang $(93,2 \%)$.

Hasil penelitian ${ }^{9}$ dikatakan ibu postpartum yang dilakukan teknik marmet menunjukkan hasil yang signifikan terhadap produksi ASI ibu merasakan aliran ASI yang keluar lebih banyak. Hal ini juga didukung dalam penelitian ${ }^{10}$ Metode lain yang dapat membantu memaksimalkan reseptor oksitosin, merangsang let down reflex dan meminimalkan efek samping dari tertundanya proses menyusui adalah dengan cara melakukan pijat oksitosin ${ }^{11}$.Pijat oksitosin merupakan salah satu solusi yang tepat untuk mempercepat dan memperlancar produksi dan pengeluaran $\mathrm{ASI}^{12}$. Hal ini di dukung dalam penelitian ${ }^{13}$ bahwa terdapat hubungan antara pijat oksitosin dengan kelancaran produksi ASI pada ibu postpartum sectio caesarea di RSIA Aisyiyah Samarinda dengan $p$ value 0,003 .

Hasil penelitian Aryani, menyebutkan ada perbedaan yang signifikan kelancaran ASI pada ibu postpartum yang pijat oksitosin lebih efektif dalam meningkatkan kelancaran ASI bila dibandingkan dengan teknik marmet, sehingga disarankan kepada petugas pelayanan kesehatan khususnya bidan untuk memberikan asuhan pijat oksitosin untuk memperbanyak produksi $\mathrm{ASI}^{14}$.

\section{METODE}

Kegiatan pengabdian masyarakat ini dilaksanakan pada bulan April sampai Juli 2019. Lokasi dilaksanakan di Klinik Tamansari Kota Pekanbaru.

a. Edukasi pada bidan tentang pijat oksitosin

Edukasi Yang dilaksanakan yaitu :pemberian materi tentang tentang pijat oksitosin dan materi tentang IMD, ASI secara ekslusif, manfaat ASI bagi tumbuh kembang anak, dan simulasi keterampilan cara pijat oksitosin di Klinik Taman Sari.

b. Praktik edukasi

Pembinaan Keterampilan Bidan dalam Melakukan Pijat Oksitosin terhadap ibu menyusui di Klinik Taman Sari yang dilakukan oleh Bidan di Klinik Taman Sari 1 sampai dengan Taman Sari 6

c. Monitoring dan evaluasi

Kegiatan Monitoring Pijat Oksitosin dan Evaluasi dilaksanakan oleh reviewer dan tim Pengabmas Poltekkes Riau dengan metode bed side teaching

\section{HASIL DAN PEMBAHASAN}

Kegiatan pada pertemuan pertama adalah pelatiahn tentang pijat oksitosin kepada semua bidan yang bekerja di klinik Taman Sari. Kemudian Bidan diberi penjelasan pengertian, tujuan, manfaat, program dan pentingnya melakukan Pijak Oksitosin dalam upaya memperbanyak ASI. Setelah Bidan mengerti dan bersedia melakukan pijat oksitosin kepada setiap ibu habis melahirkan di Klinik Taman Sari. Peserta berjumlah 29 orang.

\subsection{Pertemuan I}


Sebelum pelaksanaan pelatihan, ketua pelaksana memberikan inform consent kepada Bidan di Klinik taman Sari untuk bersedia mengikuti kegiatan sampai selesai dan bersedia nantinya mengajarkan suami/ keluarga tentang pijat oksitosin. Pelatihan dilakukan selama 2 jam / hari meliputi ceramah dan diskusi mengenai Pijat oksitosin, manajemen laktasi, dilanjutkan dengan simulasi keterampilan pijat oksitosin.

Kegiatan proses pelaksanaan pada tahap pertama diberikan pengetahuan dan latihan mengenai IMD dan ASI eksklusif, manfaat dan keunggulan ASI, fisiologi laktasi, dan manajemen laktasi, dalam bentuk ceramah/diskusi/demonstrasi. Pada sesi ke dua Bidan - Bidan mensimulasikan teknik pijat oksitosin didampingi oleh tim berlatih bersama bidan - bidan (role play).

Materi pemberian ASI bertujuan untuk meningkatkan pengetahuan dan kesadaran Bidan tentang Upaya memperbanyak ASI dan manfaat ASI sehingga ibu mau memberikan ASI pada bayinya secara eksklusif selama 6 bulan. Dalam hal ini juga dilakukan diskusi interaktif diantara peserta dengan menceritakan pengalaman menyusui, kemudahan dan kesulitan, cara menyusui,cara perawatan payudara dan masalah didalam menyusui.

\section{a. Pengetahuan Sebelum Pembinaan}

Tabel 2.1

Pengetahuan Bidan Tentang Pijat Oksitosin Sebelum Pelatihan di Klinik Taman Sari Kota Pekanbaru

\begin{tabular}{lcc}
\hline \multicolumn{1}{c}{ Pengetahuan } & Frekuensi & Persentase \\
\hline Tinggi & 6 & 20 \\
Rendah & 23 & 80 \\
\multicolumn{1}{c}{ Total } & $\mathbf{2 9}$ & $\mathbf{1 0 0}$ \\
\hline
\end{tabular}

Berdasarkan tabel 2.1 diketahui mayoritas responden memiliki pengetahuan rendah tentang pijat oksitosin sebelum pelatihan yaitu sebanyak 23 orang (80\%).

Dalam diskusi ini peserta akan saling berbagi pengalaman tentang pijat oksitosin dalam upaya memperbanyak ASI dan tim pengabmas akan membantu bidan memantau penerapan pijat oksitosin terutama dimana area/ tempat pemijatan dan posisi jari saat memijat.

Pembinaan tentang pijat oksitosin dilakukan oleh Bidan di klinik Taman Sari kepada ibu nifas dan suami beserta keluargannya untuk kelanjutan teknik pijat oksitosin di rumah ibu nifas setelah pulang dari Klinik Taman Sari. Pengetahuan adalah merupakan hasil dari tahu dan ini terjadi setelah orang melakukan pengindraan terhadap obyek tertentu. Penginderaan terhadap obyek terjadi melalui panca indra manusia, yakni: penglihatan, pendengaran, penciuman, rasa, dan raba. Sebagian besar pengetahuan manusia diperoleh melalui mata dan telinga. Pelatihan dilakukan untuk meningkatkan pengetahuan Bidan dalam penerapan teknik pijat oksitosin kepada suami/ keluarga ibu nifas dan mengingatkan pemberian ASI baik pada bayi dan anak dapat meningkatkan pertumbuhan dan perkembangan anak bangsa maka perlu lebih sering diberikan informasi tentang Upaya memperbanyak ASI, teknik menyusui, bahaya yang mungkin timbul bila ASI kurang cukup untuk bayi dan bagi ibu menyusui.

\subsection{Pertemuan II}

Kegiatan ke 2 adalah memantau penerapan tentang pijat oksitosin di klinik Taman Sari 2, dimana Tim pelaksana pengabdian masyarakat menilai Bidan saat melakukan pijat oksitosin ke setiap ibu nifas. Pada saat evaluasi Keterampilan bidan melakukan pijat oksitosin semua sudah sesuai dengan daftar cheklist prosedur intervensi penerapan pijat oksitosin, dan dari semua ibu bersalin tersebut minta suaminya yang melakukan pijat oksitosin.

\subsection{Pertemuan III}

Kegiatan ke 3 adalah memantau penerapan tentang pijat oksitosin di klinik Taman Sari 5, dimana Tim pelaksana pengabdian masyarakat menilai Bidan saat melakukan pijat oksitosin ke 
setiap ibu nifas. Pada saat evaluasi Keterampilan bidan melakukan pijat oksitosin semua sudah sesuai dengan daftar cheklist prosedur intervensi penerapan pijat oksitosin, dan dari semua ibu bersalin tersebut minta suaminya yang melakukan pijat oksitosin.

\subsection{Pertemuan IV}

Kegiatan ke 4 adalah memantau penerapan tentang pijat oksitosin di klinik Taman Sari 6, dimana Tim pelaksana pengabdian masyarakat menilai Bidan saat melakukan pijat oksitosin ke setiap ibu nifas. Pada saat evaluasi Keterampilan bidan melakukan pijat oksitosin semua sudah sesuai dengan daftar cheklist prosedur intervensi penerapan pijat oksitosin, dan dari semua ibu bersalin tersebut minta suaminya yang melakukan pijat oksitosin. dan ada lorang ibu nifas minta ibunya (ortu) yang membantu memijat.

\subsection{Pertemuan V}

Kegiatan ke 5 adalah memantau penerapan tentang pijat oksitosin di klinik Taman Sari 1, dimana Tim pelaksana pengabdian masyarakat menilai Bidan saat melakukan pijat oksitosin ke setiap ibu nifas. Pada saat evaluasi Keterampilan bidan melakukan pijat oksitosin semua sudah sesuai dengan daftar cheklist prosedur intervensi penerapan pijat oksitosin, dan dari semua ibu bersalin tersebut minta suaminya yang melakukan pijat oksitosin.

\subsection{Pertemuan VI}

Kegiatan ke 6 adalah memantau penerapan tentang pijat oksitosin di klinik Taman Sari 4, dimana Tim pelaksana pengabdian masyarakat menilai Bidan saat melakukan pijat oksitosin ke setiap ibu nifas. Pada saat evaluasi Keterampilan bidan melakukan pijat oksitosin semua sudah sesuai dengan daftar cheklist prosedur intervensi penerapan pijat oksitosin, dan dari semua ibu bersalin tersebut minta suaminya yang melakukan pijat oksitosin..

\subsection{Pertemuan VII}

Kegiatan ke 7 adalah memantau penerapan tentang pijat oksitosin di klinik Taman Sari 3, dimana Tim pelaksana pengabdian masyarakat menilai Bidan saat melakukan pijat oksitosin ke setiap ibu nifas. Pada saat evaluasi Keterampilan bidan melakukan pijat oksitosin semua sudah sesuai dengan daftar cheklist prosedur intervensi penerapan pijat oksitosin, dan dari semua ibu bersalin tersebut minta suaminya yang melakukan pijat oksitosin.

Tabel 2.2

Pengetahuan Bidan Tentang Pijat Oksitosin Sebelum Pelatihan di Klinik Taman Sari Kota Pekanbaru

\begin{tabular}{lcc}
\hline \multicolumn{1}{c}{ Pengetahuan } & Frekuensi & Persentase \\
\hline Tinggi & 21 & 73 \\
Rendah & 8 & 27 \\
\multicolumn{1}{c}{ Total } & $\mathbf{2 9}$ & $\mathbf{1 0 0}$ \\
\hline
\end{tabular}

Berdasarkan tabel 2.2 Berdasarkan hasil post test diperolah hasil terjadinya peningkatan pengetahuan Bidan tentang pijat oksitosin, diketahui mayoritas responden memiliki pengetahuan yang tinggi setelah pelatihan yaitu sebanyak 21 orang $(73 \%)$.

Setelah dilakukan pengukuran pengetahuan pre test dan post test diperolah hasil terjadinya peningkatan pengetahuan bidan tentang pijat oksitosin didapatkan hasil pengetahuan Bidan sebelum pelatihan mayoritas rendah sebanyak $80 \%$ dan setelah pelatihan berkurang menjadi $27 \%$. Ini menunjukkan bahwa sebagian bidan - bidan sesudah mengikuti pelatihan sudah paham tentang cara melakukan pijat oksitosin.

Kegiatan pengabdian masyarakat berupa pembinaan keluarga ibu nifas (suami) berperan dalam upaya memperbanyak ASI ibu "Suami Sayang Istri dan si buah Hati" Pembinaan penerapan pijat oksitosin ini dengan titik berat upaya kesehatan promotif \& preventif untuk meningkatkan 
segala daya upaya yang membantu ibu mencapai keberhasilan dalam menyusui bayinya. Usaha ini dilakukan terhadap dalam tiga tahap, yakni pada masa kehamilan (antenatal), sewaktu ibu dalam persalinan sampai keluar rumah sakit (perinatal), dan masa menyusui selanjutnya sampai anak berumur 2 tahun agar dapat mencapai mutu generasi yang berkualitas dan berdaya guna dalam kehidupan keluarga dan masyarakat.

Pengetahuan adalah merupakan hasil dari tahu dan ini terjadi setelah orang melakukan pengindraan terhadap obyek tertentu. Penginderaan terhadap obyek terjadi melalui panca indra manusia, yakni: penglihatan, pendengaran, penciuman, rasa, dan raba. Sebagian besar pengetahuan manusia diperoleh melalui mata dan telinga. Pelatihan dilakukan untuk meningkatkan pengetahuan bidan tentang pijat oksitosin untuk memperbanyak ASI pada bayi dan anak dapat meningkatkan pertumbuhan dan perkembangan anak bangsa maka perlu lebih sering diberikan informasi tentang teknik pijat oksitosin kepada setiap ibu bersalin.

\subsection{Penerapan Keterampilan Pijat Oksitosin}

Kegiatan observasi keterampilan penerapan pijat oksitosin di klinik Taman Sari, dimana tim pelaksana pengabdian masyarakat menilai bidan saat melakukan pijat oksitosin ke setiap ibu nifas. Observasi terhadap keterampilan bidan melakukan pijat oksitosin sebanyak tiga kali pengamatan sesuai dengan daftar cheklist prosedur intervensi penerapan pijat oksitosin, dan dari semua ibu bersalin tersebut minta suaminya yang melakukan pijat oksitosin.

Tabel 2.3 Keterampilan Bidan Tentang Pijat Oksitosin
di Klinik Taman Sari Kota Pekanbaru

\begin{tabular}{ccc}
\hline Observasi & Rerata & Persentase \\
\hline I & 10,2 & 67,8 \\
II & 13,1 & 87,1 \\
III & 15 & 100 \\
\hline
\end{tabular}

Berdasarkan tabel 2.3 hasil observasi keterampilan bidan dalam menerapkan pijat oksitosin, pada observasi pertama rerata 10,2 atau $67,8 \%$, observasi ke dua rerata 13,1 atau $87,1 \%$ dan pada observasi ke tiga sudah kompeten melakukan pijat oksitosin dengan rerata 15 atau $100 \%$.

Keterampilan adalah kecakapan yang berhubungan dengan tugas-tugas sesuai dengan analisis pekerjaan yang meliputi: persyaratan pendidikan, kebutuhan pelatihan dan pelaksanaan pekerjaan secara sukses ${ }^{15}$. Keterampilan bidan melakukan pijat oksitosin merupakan hasil dari latihan yang berulang-ulang dapat disebut perubahan yang meningkat dan progresif oleh bidan yang mempelajari keterampilan ini, sebagai hasil dari aktifitas sehari hari- hari di klinik bersalin. Pembentukan keterampilan bidan lebih baik ini karena sebagian dari bidan sudah mendapatkannya di saat mengikuti pendidikan Diploma III kebidanan dan diingatkan kembali saat pendampingan pemijatan Oksitosin sehingga saat evaluasi bidan sudah terbiasa melakukannya dan sudah sesuai dengan daftar cheklist prosedur intervesni penerapan pijat oksitosin. 


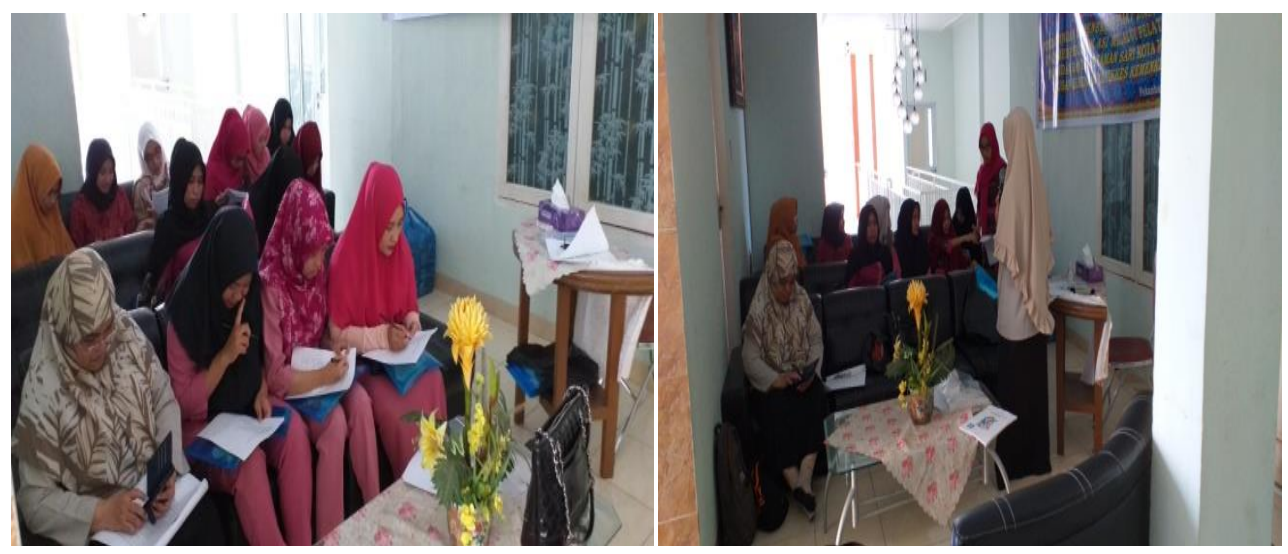

Gambar 1 Pelatihan : Pijat Oksitosin
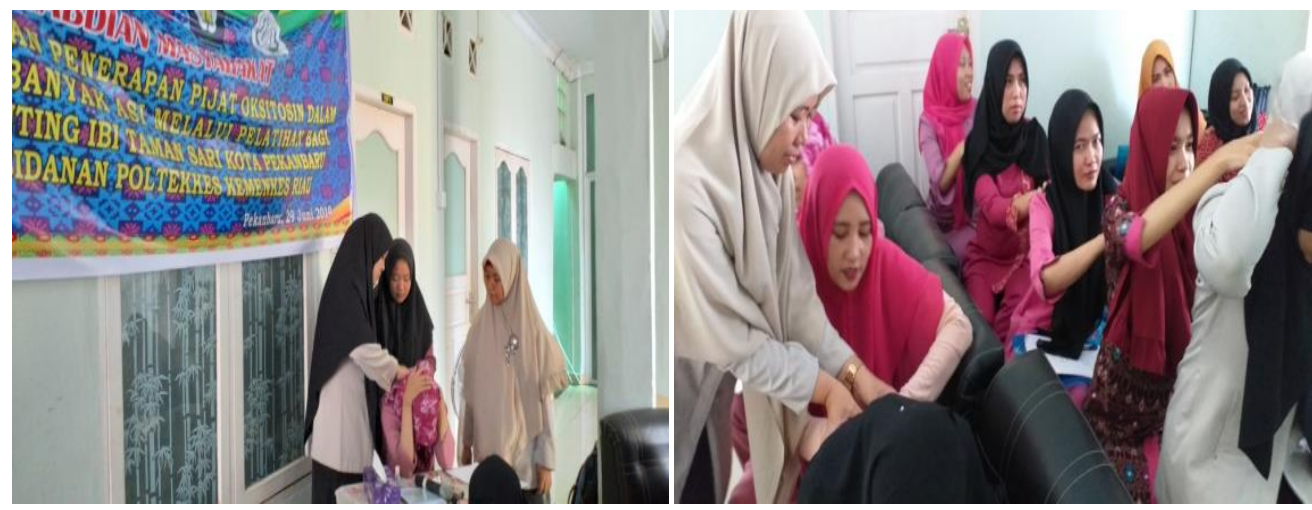

Gambar 2. Demostrasi Keterampilan Praktik Pijat Oksitosin

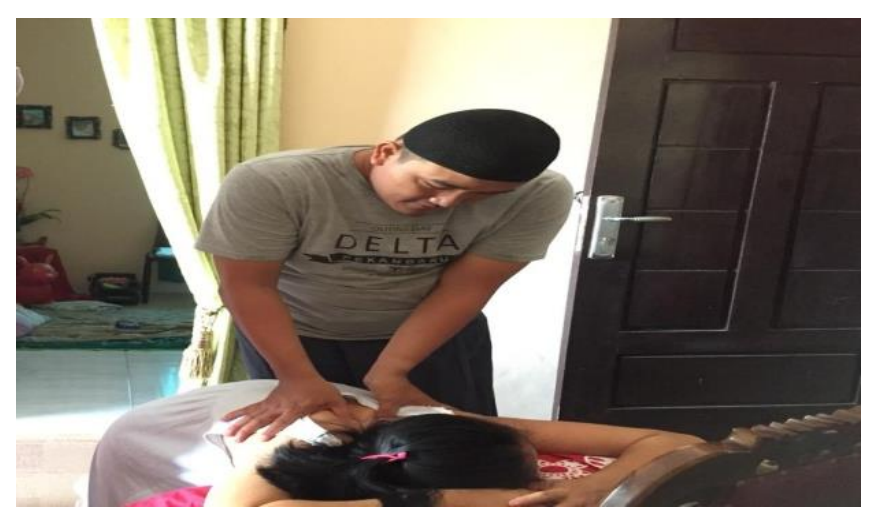

Gambar 3. Ayah Sedang Melakukan Pijat Oksitosin

\section{KESIMPULAN}

Berdasarkan hasil laporan pengabdian masyarakat ini dapat diambil kesimpulan sebagai berikut:

1. Terdapat peningkatan pengetahuan bidan tentang Pijat Oksitosin di klinik Taman Sari sebanyak $53 \%$

2. Terdapat peningkatan Keterampilan bidan Melakukan Pijat Oksitosin di Klinik taman Sari sebayak $32,2 \%$

3. ASI ibu menyusui sudah lancar dan saat pulang sudah memberikan ASI pada Bayi.

\section{SARAN}


Perlu adanya edukasi secara langsung, tenaga kesehatan dan juga dapat membagikan leafleat tentang pijat oksitosin dan menempel foto-foto tentang pijat oksitosin di dinding tempat pelayanan kesehatan.

\section{UCAPAN TERIMA KASIH}

Penulis mengucapkan terima kasih kepada:

1. Hj. Husnan, SKp,MKM selaku Direktur Poltekes Kemenkes Riau

2. Elmi YN, SKM selaku Pimpinan Klinik Taman Sari Group Kota Pekanbaru

3. DR.Aslis Wirdahayati dan Rully Hevrialni, S.ST, M.Keb sebagai Tim Reviwer Poltekkes Kemenkes Riau yang memberi masukan dan kritikan untuk kegiatan Pengabmas ini.

4. Lailiyana, SKM, M.K.M, selaku Ketua Jurusan Poltekkes Kemenkes Riau dan seluruh rekan dosen jurusan kebidanan

\section{DAFTAR PUSTAKA}

[1] WHO. (2009). Infant and young childfeeding. Geneva:World health organization.

[2] AAP section on breastfeeding. (2012). Breastfeeding and the use of human milk. Journal pediatric care online.

[3] Kemenkes RI. (2013). Riset kesehatan dasar (Riskesdas). Jakarta: Badan penelitian dan pengembangan kesehatan kementrian kesehatan RI.

[4] Sugiarti, E., Zulaekah, S., \& Puspowati, D. S. (2011). Faktor-faktor yang berhubungan dengan pemberian ASI eksklusif di kecamatan karang malang kabupaten sragen. Jurnal kesehatan, ISSN 1979-762. 195-206.

[4] Direktorat Bina gizi, Kemenkes RI. (2015). Pelatihan Konseling Menyusui. Jakarta: Kemenkes RI

[5] Afifah, D. N. (2007). Faktor yang berperan dalam kegagalan praktik pemberian ASI eksklusif. Skripsi. Semarang:PSIK FK Undip.

[6] Kodrat. (2010). Dahsyatnya ASI \& Laktasi Untuk Kecerdasan Buah Hati Anda. Yogyakarta: Medika Baca.

[7] Yaqub, A \& Gul, S. (2013). Reason for failure of exclusive breastfeeding in children less than six month of age. Diperoleh dari http://www.ayubmed.edu.pk/JAMC/251/AsmaYaqub.pdf pada tanggal 15 Januari 2019.

[9] Widiastuti, A., Siti, A., \& Wiwin, R. R. (2015). Pengaruh teknik marmet terhadap kelancaran air susu ibu dan kenaikan berat badan bayi. Jurnal Kesehatan Masyarakat Nasional. Poltekes Semarang

[10] Ulfah, R. R. M. (2013). Efektifitas pemberian teknik marmet terhadap pengeluaran ASI pada ibu menyusui 0-6 bulan di wilayah kerja puskesmas arjasa kabupaten jember. Jember: PSIK Univeristas jember.

[12] Evariny, A. (2008). Agar ASI lancar di awal masa menyusui. http://www.hypno birthing.web.id/?, diperoleh tanggal 20 Desember 2018.

[13] Biancuzzo, M. (2003). Breastfeeding the newborn. Clinical Strategies for nurses. St. louis: Mosby.

[14] Albertina, M., Melly., \& Shoufiah, R. (2015). Hubungan pijat oksitosin dengan kelancaran produksi ASI pada ibu postpartum sectio sesarea hari ke 2-3. Jurnal Husada Mahakam.

[15] Ariani,Y dkk, (2018). Perbedaan Kelancaran ASI Pada Ibnu Post Partum Yang Dilakukann Teknik Marmet dan Pijat Oksitosin di Kloinik Taman Sari 2 dan BPM Rosita Kota Pekanbaru, Pekanbaru 